\title{
THE SPECTRUM OF ESTHETIC CATEGORIES IN WORKS OF STANISLAV ORIHOVSKY (1513-1566)
}

\author{
Ruslana Mnozhynska \\ Candidate of Philosophy Sciences, Associate Professor, \\ Kyiv National University of Technology and Design, Ukraine \\ e-mail: ruslanamnozhynska@gmail.com,orcid.org/0000-0001-8459-3496
}

\section{Summary}

For a long time, Ukrainian and Western European scientists have included all the Latin works to the Catholic values and brought exclusively to Polish literature, and therefore denied the penetration of humanism and Renaissance within the boundaries of the Orthodox Eastern Slavonic world, forgetting that Ukrainian scientists, to which Stanislav Orikhovsky belongs, not indirectly through Polish teachings acquired leading pan-european ideas, but themselves were part of the european renaissance intelligency.

In the culture of Ukraine XIIII-XVII centuries there are no interpretations on esthetic issues. However, there are grounds to consider certain reflections on the problems of art and art work in connection with questions of faith and its symbols, values of knowledge and role of sensual experience in the cognitive activity, values of indifferent attitude of a person to the world and to faith and earthly destination of a person. Now, brought into the scientific circulation little known, and even quite unknown, mainly Latin sources strongly testify that the epoch of revival, with its esthetic ideals, has not passed Ukraine as a component of Europe.

Stanislav Orikhovsky (1513-1566) is one of the most prominent personalities in the Ukrainian and Polish culture of Renaissance: Philosophy, historian, publicist, polemist, esthette, speaker.

The article focuses on the fact that one of the first, in the national renaissance cultural opinion, who considered the question of esthetics was Stanislav Orikhovsky. In works on esthetics, he devoted a lot of his place to problems of good and evil, as a humanist put the importance of man in dependence on her personal qualities, personal integrity, talent and ability to realize them.

Interest in esthetics was revealed clearly, complete it, quite concrete content. In his works he considered and outlined ways of solving various problems, in particular, ethical and esthetic.

The spectrum of esthetic categories of the Orikhovsky is mainly represented by the following: Heroic, beauty, beautiful - creative; raised - low; harmony is chaos. AND parts: Comic - tragic; irony, mezzis.

Keywords: Esthetic ideal, harmony, symmetry, honesty, spirituality, irony, humanism.

DOI: https://doi.org/10.23856/4610

\section{Introduction}

Becoming Stanislav Orikhovsky Roksolanin, his heritage in the field of esthetics only begins to be part of the context of national cultural opinion. Now in scientific circulation the works of the thinker are introduced, translated by modern Ukrainian language. The task of culturologists is to write this to the history of culturological science. 
The purpose of this article is to look at the esthetic ideas of the thinker in a new way, to determine the essence of his vision of the genesis of esthetic categories. The relevance and novelty of the investigation is that it presents a whole range of esthetic categories in the heritage of the thinker and analyzes philosophical-esthetic views S. Orykhovsky in the context of the polyphony of ideas of the good of revival, taking into account the fact that heritage S. Orykhovsky for a long time was the subject of studying only Polish scientists.

The article examines one of the important aspects of S. Orykhovsky's activity, namely the range of esthetic categories, which was supported by the scientist in his works, the creative ways of which significantly influenced the further development of spiritual and cultural processes not only in Ukraine, but also in Poland. All this is not yet sufficiently studied, although the need for such a kind of knowledge is great.

\section{Natural and esthetic genesis}

Ancient thinkers in their works, tried to reveal the essence and nature of esthetic, in particular beautiful, and expressed on this occasion a number of interesting and deep thoughts. Special merit in this matter belongs to Aristotle, «Poetry» which can be considered a treatise from esthetics. The medieval esthetics were formed in new historical conditions, when feudalism came to change the slave-master society, and the form of consciousness and spiritual influence, in particular in Europe, became Christian religion. Quite another idea about esthetic was formed in the epoch of revival, esthetic consciousness of which in general has a transitional character and contains tendencies both ancient and medieval, and the next stage of esthetic thought. A significant influence on the formation of consciousness at this time has been made by a panel anthropocentric world through which art has become the leading form of public consciousness. From now on, as in antiquity, the main attention is paid to the person and her earthly life, artistic form, which is an optical integrity and order, which correspond to reality; proportions of the human body are proclaimed by the canon of artistic image. Alberti, Leonardo da Vinci, Dürer and other artists, as well as art theorists, directed the development of esthetics on the art-policy path. Beauty and its contemplation are in them a kind of spiritual set, which is not addressed to anything specifically, and at the same time is an invaluable asset of the individual (Orikhoviana, 1891).

If we talk about Ukrainian renaissance hunters, theoretical considerations about esthetic problems can not be found frequently in their works. The same to personality Orykhovsky, then he interest in esthetics revealed clearly, but he filled it, quite concrete content. The spectrum of esthetic categories of Orikhovsky is drawn mainly by the following: Heroic, beauty, beautiful creative; raised - low; harmony is chaos. And parts: Comic - tragic; irony, mezzis. In this article we will stop only three: Heroic, beautiful, beautiful.

\section{Understanding the heroic category}

In the middle ages people appreciated and became famous primarily for aristocratic origin, age of family, titles. So social inequality of people was formed. Noble respect was an inseparable sign of high origin: Only aristocrat was recognized as capable of true greatness of soul, heroic pupils. Instead, the humanists set the importance of the person depending on her personal qualities, personal integrity, talent and ability to realize them. The representative of aristocratic family, according to the humanists, should earn a chance of their noble deeds, their heroic deeds or worthy memory of the descendants of the public, or charitable activity, etc. The nobility of the intellect, not the origin, the value of the person for her personal merits, not 
for aristocratic titles, were the basis of the thoughts about the man. In Ukraine, these humanistic principles have been based on or not the most consistent personality Orikhovsky, who wrote that kindness and kindness are not inherited from parents, as name and estate, but acquired. $\mathrm{He}$ criticized those who, proud of their origin, without knowing, in fact, what is the nobility, and in the address to the king advised him to surround himself by advisers not for title, but by their abilities and practical deeds. Orykhovsky also stood on the position of equality of all states of society before God and the law, and believed that none of them had a mental advantage over others. And therefore, he concluded that they do not deserve the higher happiness in the social hierarchy, those who «are there only because of their origin» (Orikhoviana, 1891).

Works of art Orykhovsky was inhabited by a large genre diversity. Samples for investigation he finds mainly in ancient historical literature and modern. The outstanding figures of history were for him the same «engines of history», and therefore their actions and pupils consider the expensive investigation, and they all propagate and break. The most worthy for investigation was considered the antique heroes of the homerevsk poet; Macedonian kings Filipa and Alexander the Great; Persian monarchies - Kira, Kserksa; roman military and political figures; Ancient Greek commanders and statesmen - Pavsania, Pericles, Temistoklahat, etc.

From the mythological heroes the most popular was Hercules (Hercules). The characteristic feature of the views of Orikhovsky was his conviction in the possibility of influence on the course of historical events, not only Christian God, but also other supernatural forces. Their implementation is primarily the anti-Olympic gods; as well as anti-hero and mythological characters, etc. Especially honored our hunter fate (Fortunu), which crowns its elected members, does not help them; it can be generous, happy for those who care about their honor and glory. From the lava of fate talent in battle; from it «at least, nowhere to get», it is subordinate kings and princes; They believe in the fate, even though it is sometimes unspoken even with the great princes; there is a crime, a betrayal; may be taken away. At the same time, it is not omnipotent, inferior to human kindness and importance, and is not presented too high if people themselves do not promote it (Kshyshtof, 2004).

The heroization of personality, the emphasis of individual positive qualities (bravery, nobility, etc.) was characteristic for culture of the epoch of revival and its philosophical basis was renaissance nepoplatonism. Such heroization of the personality with an emphasis on its solid activity was characteristic and Ukrainian XV - the honor. XVII century Life in Ukraine of that time was dynamic, dramatic and very controversial. Historical circumstances required the characteristics of strict, free, power, capable of decisive actions. The personalities with such traits have been outlined, in particular, S. Orykhovsky. The subject of his historical reports was the action of prominent personalities, eminent «heroes» of historical days, their actions and pupils considered to be an example and an example for investigation. Orykhovsky wrote both about the welfare of the Polish hat and about the military flight of Ukrainian Cossacks, which they witnessed in the struggle against Turkish-Tatar aggression. Drawing one of such battles, which took place under Sokal, he heroine behavior in fight Fredrija Gerburt, as well as courageous not to retreat from worldly affairs and transition to ascetic mobility, and in noble heroic deeds, in service of the welfare as the highest goal is seen by our hunter the meaning of life. They were united with him and kept the pressure of the tatar army in a fearless manner.

\section{The range of beauty in the Renaissance sense}

Beauty - an aesthetic category, which means perfection, a harmonious combination of aspects of the object, in which the latter causes the observer aesthetic pleasure. Beauty is the 
most important category of culture. In its aesthetic perception, the concept of beauty is close to the concept of beauty, with the difference that the latter is the highest degree of beauty. However, beauty is a more general and multifaceted concept, largely eclectic. The opposite of beauty is ugly. In the Renaissance, instead of the popular in the Middle Ages definition of memento mori (the meaning of which was the argument of neglect of earthly life and preparation for the afterlife), there is a new slogan of humanists - memento vivere (remember to live) - means: here on earth. The human becomes the object of study, its earthly tastes, joys, feelings are rehabilitated. Literature and art glorify the beauty of the world of nature and man in it. Artists define the laws of beauty, which, according to Dürer, cannot be calculated mathematically and which are therefore not absolute, but based on «human judgment», find their highest justification where they can rely not only on mathematical and logical justification, but also on experimental necessity, when they are based not on the imagination of one person, but on the nature of this reality. Art is derived from the vast experience of «knowledge of the mind of nature» (ratio naturae). «Because, indeed, art is hidden in nature; whoever can get it from there, he has it.» Art, according to Dürer, has two equal points of reference: reality and reason. Renaissance anthropocentrism is now based on the following indisputable truths. (Lytvynov, 2000).

As for Orikhovsky, the category of beauty appears in his works very often and in a wide range. His oratory can be beautiful (eloquence, style of speech, locality, ideas, forms. The works of the thinker are beautiful and perfect. In particular, the Italian humanist Paul Ramnuziy wrote to Orikhovsky in the preface to The Reader: In my opinion, the speech you gave at the funeral of King Sigismund of Poland contains, and conceals, much more than it seems at first glance. the placement of certain parts of it - all this leads me to think that the speech is worthy to be read by even the most learned. And I will gladly make sure that it is published for the use of scientists. end: I don't want what we present for thoughtful reading to be neglected until it is fully understood. that Rusyn. (Kshyshtof, 2004).

The Italian did not spare Orikhovsky words of surprise and affection as the first Polish writer in whose works he saw a treasure trove of beauty. Polish contemporaries also spoke about Orikhovsky's extraordinary and multifaceted talent. Thus, the famous Polish figure Fritz Modzewski wrote that Orikhovsky «adorned Poland with science and numerous testimonies of his talent.» Perfection and beauty of the form of our thinker's works were noted by later Polish researchers. Thus, in Orikhovsky's speeches T. Sinko saw the «treasury of beauty», drawing attention to the «accuracy of argumentation and the beauty of the form» Turk «, although he added that the author owes this to Demosthenes and Cicero». (Losev, 1978) Finally, Keller, as if summarizing all the positives in Orikhovsky's work, notes that Orikhovsky himself became «an ornament of his Russia, which for him was synonymous with simplicity and severity, as well as synonymous with healthy morality and purity of faith» (Lytvynov, 2000).

Completely in the Renaissance spirit, S. Orikhovsky composes a real anthem of female beauty, especially in the work «On Celibacy». We are excited by the temptations of the female body when we not only see it, not only hear about it, but even when we think about it. «All Orikhovsky's apologetic, laudatory statements about women should not be listed. in our opinion, it is as if the quintessence in his eulogies to a woman-wife, mother, beloved: A woman wins everything and surpasses everything. The ancients marveled at its beauty and compared it not with some decay, a low-value thing, but with the sun itself, the radiance of which illuminated everything. Therefore, a woman, who is the light and decoration of a man's house, is rightly considered to be some kind of sun in human life» (Orikhoviana, 1891).

That is why even the wisest and very strict philosophers consider the young ephebes to be iron and strange because they are not touched by their beauty when they meet women, and 
the girl they meet does not disturb their hearts. The Supreme Court of all Greece has accused the famous prostitute Frina in a criminal case. When she could not be protected lawyers, she tore her clothes and exposed the Persian. In this way she defended herself: amazed by the charm and beauty of her body, the judges released the girl. That's how much nature weighs, that's what a woman's beauty can do even in court. Neither the eloquence of the lawyers nor the integrity of the judges resisted her charms.» (Kshyshtof, 2004).

Distinguishing the aesthetic categories of beauty and beauty, which are unique to women, Orikhovsky, however, notes: The weaker a woman than a man, the stronger the mistress is due to its charms, which have a special power that captivates the souls of men. Women confuse us so much that even if we wanted to, we did not have the strength to get rid of them. At the same time, Orikhovsky notes that beauty (beauty, charm) is a powerful weapon of women that no knight could resist. Therefore, the question arises: who does not like whom? Rotterdamski also pondered this question, writing: «To take at least external beauty, its women are rightly valued above all in the world and with its help tyrants even tyrants». (Orikhovskyi, 2004).

As for the beauty of speech, eloquence, the ancient philosophy and all ancient literature, we can say was permeated with elements of arrogance, which Plato in his aesthetics put almost in the first place. At the same time, he singled out two points: a political speech seeks first of all to convince the listener, and a solemn speech seeks to please the listener. Thus, in the first case, the most important was the power of speech, and in the second - considered the most important beauty - the beauty of form. Eloquence, as the ability to speak beautifully, inspiringly, convincingly was highly valued in Europe and later, in the Renaissance. In Ukraine, the art of eloquence was highly valued by Orikhovsky, who himself had a remarkable oratory, «without which, he believed, not only civil peace but also external war could not do.» He cites an interesting episode from ancient times: «When Philip, Alexander's father, defeated the Athenians at Heronea, he clapped his hands with great joy, running among the army and shouting:, I defeated you!» And that Demosthenes did not take part in the battle. But because on the advice and persuasion of Demosthenes the Attians began to fight against Philip, he believed that he had defeated not Attica, but Demosthenes himself, whose language the king feared more than the troops of the Attians» (Orikhovskyi S. Vybir tvoriv, 1972). Scientist T. Sinko, Oreshovsky owes to Demosthenes the ability to argue, and Cicero - the influence of the spoken word. (Losev, 1978).

Orikhovsky studied eloquence directly in Italy, in particular, in Bologna, as he himself tells (Roterdamskyi, 1993). As a result, Orikhovsky himself soon became a role model at home and a source of pride abroad, where he was also known and popular. Here, for example, is what the well-known Polish historian Cromer wrote in the already mentioned letter to Orikhovsky about this: And I was proud of your glory, because I see in you my compatriot and friend, and therefore the rays of your glory fall on me» (Synko, 1939). According to the Ukrainian thinker, language is a great gift: it created the state, gave rights to people, built cities, taught all the virtues of people and finally showed them the way to activity and spiritual salvation»" (Synko, 1939) king about the improvement of the old and the establishment of new «schools of eloquence», which would be the necessary speach.

\section{The category of beauty}

Beautiful is a category of aesthetics, which expresses the facet of aesthetic development of the world, which corresponds to the ideal of man and is accompanied by a sense of aesthetic pleasure. The measure of beauty is symmetry, harmony, proportion, the ensemble of its natural properties. Among other aesthetic categories, special attention is paid to the beautiful. It tops 
the list of aesthetic values and is an indicator of spirituality and humanity, perfection and freedom, and the main concept of aesthetics as a science. Beautiful for man in nature, in society and in himself, is everything in which he finds perfect and life-affirming, desirable and harmonious, selfless and ennobling. Therefore, beauty is as important and necessary for man as good, good and happiness, will and creativity. As without happiness, so without beauty the destiny of the person loses sense, and life - prospects. Striving for beauty, a person has important values and is active, overcomes obstacles and fights for their implementation. In contrast to the ancient notion of nature as an eternal and beautiful fact, as well as its medieval understanding as a result of the creation of a supernatural personality, Renaissance man first felt nature as an aesthetically significant concreteness, as a subject of disinterested self-sufficient contemplation and pleasure. For Renaissance man, nature was a spiritually rich, beautiful reality, which she sought to master artistically.

As for Orikhovsky, he operates in the category of «beautiful» most often in three cases: when he talks about women, the form of government in Poland and art. The woman in him is the most tender, the most charming, the most pleasant that nature has created. And who gave her husband a woman as a wonderful means of consolation to which to go. Therefore, marriage is the best form of relationship between men and women. Therefore, celibacy contradicts «the best guides in life - nature and common sense» (Kshyshtof, 2004). Women, I swear to God, have more pleasure than men of prudence, more charm than we have, more order to which we go. At the same time, he calls the witnesses of the biblical wives of Samson, David or Solomon, but also the example of the prostitute Phryna. (Lytvynov, 2000).

Orikhovsky mastered the political theories of ancient philosophers, especially Plato and Aristotle, whose works were about the «best» system of government, but thought quite original. The best, in his opinion, form of government is a class monarchy, in which the king is elected, but not by all the people, but only the nobility, vol. the thinker prefers a class of monarchy in which the king's power would be limited by law. The kingdom, according to Orikhovsky, is the best state system primarily due to the election of the king and the subordination of everything in the state to the laws. The course of Orikhovsky's thoughts led to the recognition of the monarch as a noble king. He therefore rejected the thesis of the heredity of the throne. The elected ruler became the executor of the will of the nobility: what could be more beautiful than that the one whose power you have the highest and who was not born a king, but you made him king, would use the sword you gave him, only according to with your will? «As for the laws, they are the best, according to the thinker, when all citizens participate in their creation» (Kshyshtof, 2004).

Regarding the artistic preferences of Art. Orikhovsky, there is not much evidence here, but they are there. And that is quite significant. In particular, as already mentioned, he met in Wittenberg with prominent German artists Albrecht Dürer and Lucas Cranach the Elder. He later even interpreted Dürer's artistic credo, praising the Germans precisely for «combining exceptional courage with outstanding wisdom and respecting all the arts, all the fine sciences that belong to human virtues» (Synko, 1939). Orikhovsky was not an artist, but he had an excellent oratory and writing style - as evidenced by many testimonies, including the appreciation of his talent by Italian intellectuals, in particular, Paul Ramnuzi, who wrote to our thinker: «I will not allow your outstanding and beautiful the poem traveled through Poland as a work by an unknown author, while the real author is known and highly respected. I'll take care of it. " And again: "You seem to me the most worthy of your great people to know the beautiful through you. Many people liked your speech very much, the main thing is that it is full of thoughts that could only appear in the head of a well-mannered person» (Kshyshtof, 2004). 


\section{Conclusions}

The Renaissance for ethics is a period of affirmation of a new ideal of man - a person who is aware of his social and spiritual independence, freedom of will and thought. At this time there is a reorientation from the knowledge of God to the knowledge of nature and man, from theocentrism to anthropocentrism, the recognition of human self-worth, the glorification of his dignity and creative potential.

Finally, it should be emphasized that the ideas that are dominant in the works of S. Orikhovsky, contributed to the formation of national identity, a sense of patriotism, human dignity. In addition, these ideas contributed to the assertion of the value of the individual and his freedoms. Such tendencies developed in the context of the Western European humanistic society. This is valuable given Ukraine's European choice, when it is important to overcome outdated nihilistic stereotypes, including prejudice against the inability of our thinkers to philosophically and aesthetically comprehend reality.

\section{References}

Koehler Krzysztof. (2004) Stanisław Orzechowski $i$ dylematy humanizmu renesansowego[Stanisław Orzechowski and the dilemmas of Renaissance humanism].225 s. [in Polish]

Kubala L.(1908) Stanisław Orzechowski i wplyw jego na rozwój i upadek Reformacji w Polsce. [Stanisław Orzechowski and his influence on the development and fall of the Reformation in Poland] Lwów; Warszawa 175 s. [in Polish]

Losev A.F. (1978) E'stetika Vozrozhdeniya. [Aesthetics of the Renaissance] M. My'sl 300 s. [in Russian]

Lytvynov V.D. (2000) Renesansnyi humanizm v Ukraini. (Idei humanizmu epokhy Vidrodzhennia $v$ ukrainskii filosofii XV-pochatku XVII stolittia. [Renaissance humanism in Ukraine. (Ideas of humanism of the Renaissance in Ukrainian philosophy of the XV-early XVII century] $K$. : Osnovy. 700 p. [in Ukrainian]

Orikhovskyi Stanislav. Tvory. (2004) Uporiadk., perekl. z lat. ta staropol., vstupna stattia, prymitky Volodymyra Lytvynova. [Writings. Arrange, translate from Latin. and Staropol., introductory article, notes by Volodymyr Lytvynov] K. Dnipro. 269s. [in Ukrainian]

Orzechowski St.( 1972) Wybór pism. [A selection of writings] Warszawa etc. [in Polish]

Orichoviana.( 1891) Opera inedita et epistulae Stanislai Orzechowski 1543 - 1566. [Unpublished works and messages Stanislaus Orzechowski 1543 - 1566] Cracoviae. [in Polish]

Roterdamskyi Erazm. (1993) Pokhvala hluposti, abo Pokhvalne slovo Durosti, vyholoshene Erazmom Roterdamskym. [Praise of stupidity, or the word of praise of Stupidity, uttered by Erasmus of Rotterdam] Domashni besidy. K.: Osnovy 160 s. [in Ukrainian]

Stanislav Orichovii Opera: De bello adversus Turcas suscipiendo, ad Equites Polonos [Stanislav Orichovii works: The battle against the Turks have undertaken to Knights Poles] Turcica prima. Basiliae. [in Latin]

Sinko T. (1939) Erudycja klasyczna Orzechowskiego [Orzechowski's classical erudition] Cracow. 120 p. [in Polish] 